\title{
Obituary - Jan Vansina (14 September 1929 - 8 February 2017)
}

Michele D. Wagner

Jan Vansina, a pioneering scholar in the field of African history whose career spanned more than six decades, died peacefully 8 February 2017 in Madison, Wisconsin in the presence of his spouse Claudine and son Bruno.

Energetic and innovative, original and at times irreverent, Vansina was driven by a life-long sense of curiosity and skepticism that motivated him to ask expansive questions and pursue the answers with meticulous and exacting research. The larger trajectory that his scholarship would take - historicizing Africa's precolonial past - was set early in his professional life when he worked in his first professional position as an anthropological research fellow in the Belgian Congo and Ruanda-Urundi, for the Institute for Scientific Research in Central Africa (IRSAC/IWOCA) in 1952-1960. Vansina, who had recently graduated in medieval history (Catholic University of Leuven, 1951) saw parallels between oral texts of nonliterate medieval European communities which academics regarded as historical sources, and oral sources from Kuba kingdom which anthropologists regarded as ahistorical myths. He argued that if historians could apply the "rules of evidence" to reconstruct one society's history, they should be able to apply them to another. Why would precolonial African societies be uniquely resistant to historical methodology? Or, put another way, why would an African society's past not be history?

History in Africa, Volume 44 (2017), pp. 5-9

Michele D. Wagner is an Africa analyst for the U.S. Department of State, specializing in the eastern, central, and Great Lakes regions. A University of WisconsinMadison History graduate (PhD 1991) whose doctoral work Jan Vansina supervised, she worked as his post-doctoral researcher (1991-1993) elaborating his "Words and Things" methodology. She has worked on and in Great Lakes Africa as an academic, human rights specialist, and analyst for the United Nations, Human Rights Watch, and the U.S. government. E-mail: 36grelots@gmail.com

(C) African Studies Association, 2017

doi:10.1017/hia.2017.8 
The resistance Vansina met as he struggled to move his dissertation on Kuba history through Leuven's graduate history program in 1956-1957, and the criticism that he continued to face after he successfully defended it in October 1957, solidified his resolve to study African history in the era prior to European contact - and to work to counter the idea that societies without written texts had no history. In doing so, Vansina developed rigorous historical methods, and steadily produced a body of scholarship that had grown to 25 books, and about 244 articles at the time of his death. He built a 34-year career as a professor of history and anthropology at the University of Wisconsin-Madison (1960-1973, 1975-1994) and at Leuven (1973-1975), with visiting professorships and lectureships in six countries. He proudly noted that he had supervised or actively participated in the supervision of over one hundred doctoral dissertations, including 53 which he supervised or co-supervised directly.

\section{Oral Tradition}

Throughout his life Vansina remained rooted in research which was his passion and his hallmark as a scholar. From his research developed his methodological work, a response to the possibilities and limitations he saw in his data. His first major work in the area of methods was De la tradition orale. Essai de méthode historique (Tervuren, 1961; English translation Chicago, 1965), a book that derived from the research he had conducted in Congo, Rwanda, and Burundi while working at IRSAC, and a response to the naysayers he consistently encountered. The book, whose publication coincided with decolonization in many parts of the world, received broad attention not only from western scholars but especially from a new generation of nonwestern researchers engaged in producing new, postcolonial national histories.

Over time, the book led to academic acceptance of oral traditions as valid sources of history. Its use by researchers stimulated a large body of observations and critiques which Vansina incorporated in a major revision, Oral Tradition as History (Madison, 1985). Vansina had written the first edition to establish the legitimacy of his technique, but he wrote the revised edition as a guide to give researchers around the world the tools and perspectives to collect and analyze their own oral data. This, he believed, could give voice to those previously excluded from the writing of history, and give Africans and others the means to historicize ideas and issues that were of concern to them. Each translation of the book into a new language heightened Vansina's commitment to making evidence-based history available to non-academics, one of his life-long goals.

\section{Words and Things}

Vansina loved solving puzzles, mysteries, enigmas, and discovering unexpected twists. He was fascinated by clues to the past that he could derive 
from sources - all manner of sources, from art, architecture and archaeology to medicines, rituals and farming techniques. Everything learned or received could be evidence of the past - including the very words that conveyed the evidence. Language that names and constitutes is a historical source. Words, like genes, encode numerous micro-messages. Shifts in a word's sound, meaning or nuance, distribution over space and time, and co-occurrence with other words, when agglomerated, rendered large amounts of data which, when probed with an integrated set of questions, elucidated historical linguistic patterns. These patterns, Vansina asserted, expanded the horizons of what was knowable about the African past.

Throughout the 1980s, Vansina steadily mapped out occurrences over time and space of large numbers of Central African linguistic, archaeological, and cultural elements. Using hundreds of paper maps, and unaided by computer, he created map layers that could be overlaid on top of each other to look for co-occurrence. Vansina did this with enormous input from Claudine, an artist and cartographer, who shared his passion for Africa. Using this methodology, which he called "Words and Things", and comparative dating he derived from archaeological and historical linguistic chronologies, he moved backward in time, layer upon layer, producing two breath-taking studies of the remote past, or what he called "deep-down time": the encyclopedic Paths in the Rainforests: Towards a History of Political Tradition in Equatorial Africa (Madison, 1990), often regarded as a masterpiece of innovative methodology and painstaking research covering human expansion and development in central Africa over four millennia, and How Societies are Born: Governance in West Central Africa before 1600 (Charlottesville, 2004) which explored how small foraging communities coalesced into the large societies that European visitors later "discovered".

\section{Layers}

Vansina's view of a deep and dynamic past contrasts dramatically with the shallow, static "traditional Africa" that existed in the minds of many of his colonial government compatriots when he began field research in 1952. But it also contrasts with many postcolonial depictions of the African past, including historical claims made by contemporary African governments. Antecedents to Modern Rwanda: the Nyiginya Kingdom (Oxford, 2004; Madison, 2005), based on a collection of hundreds of oral traditions recorded in 1957-1962, examines the development and expansion of the ancient Rwandan kingdom. In doing so, it quietly counters Rwandan government claims of strong, sacred kings, military conquest of far-flung lands, benevolent governance of Tutsi over Hutu, and the destruction of this by Belgium. Instead, the remarkable monograph traces the absorption of older, smaller agricultural chiefdoms into an increasingly military-centered state, the multiplication of armies and their forceful expropriation of both herding and farming communities, and struggles for power at the capital that devolve into feuds, revolts, civil war, 
and massacres. The kingdom had not recovered from these crises when Germans arrived.

\section{History's Emotional Impact}

Early in his career Vansina realized the importance and intensity of people's emotional connection to their history when in 1958 at the newly established Lovanium University in Kinshasa he faced riotous students unwilling to endure yet another European-taught African history course that depicted their forebears as primitive. Their frustration with colonial histories that humiliated rather than enlightened - which Vansina understood, having grown up as an ethnic Fleming at a time when Belgian society denigrated Flemish and exalted Francophone culture - and their exasperation with foreign academics who vaunted themselves, not Congolese, as the experts of Congolese history, resonated with Vansina. It influenced the choices he made for the rest of career, from his collaborative work with African historians through UNESCO, to his work to fund graduate studies for African students, to the rigor with which he trained African students whom he realized would be pioneers and leaders in their national academies.

Vansina's personal connection with history's emotional impact grew throughout his life. His first fieldwork in the Kuba kingdom on the southern edge of the great equatorial forest in the then-Belgian Congo transformed his own identity, he wrote in Living With Africa (Madison, 1994). He maintained life-long personal relationships with his Kuba mentors, age-mates, and, later, their children. He also maintained a scholarly connection to Kuba history, revisiting it throughout his career, applying new methodologies he developed to deepen Kuba historical understanding. Although he gained recognition especially for his methodological work, Vansina gained personal satisfaction from the contributions he made to Kuba historiography, including The Children of Woot: Essays in Kuba History (Madison, 1978) and more recently Being Colonized: The Kuba Experience in Congo, 1880-1960 (Madison, 2010) and Georges Kwete Mwana's Souvenirs d'un prince Kuba du Congo (Paris, 2010).

Living with Congo and Great Lakes Africa meant living with tragedy and the burden of painful historical memory. Violent upheavals in Congo and Rwanda that Vansina experienced as a young researcher had a strong personal impact on him and on the research questions he asked later, such as his exploration of violence in his study of precolonial Rwanda. The continuing presence of violence in the region touched him in unexpected ways, including its impact on the lives of his African colleagues and former students, and influenced his thinking on colonialism, trauma and memory, and the experience of war.

Vansina turned these questions inward in the writing of his final book Through the Night Through the Day: A Flemish Belgian Boyhood and World War II (Madison, 2014). The research for this book placed him in the position of 
an "insider" critically analyzing his own history, much as he had argued Africans can do in the writing of African history. In the process of writing of this book Vansina saw with ever greater clarity history's emotional importance to its subjects.

Having written a history that was intimately familiar to him, and experienced the intensity of the connection between history and identity firsthand, Vansina wrote a final essay "De Vita Sua" (2016) that argued that the ideas, issues and questions relevant African people should be among the drivers of African history, not incidental to it.

My conviction no doubt is the result of decades of work with persons as oral sources, rather than with impersonal writings. I have instead witnessed directly the pent-up demand of so many Congolese, and other Africans who have sought a history that is meaningful to them. For me the craft of the historians carries a social obligation to reciprocate the legacy of information we have received from those who have lived the past. In my view, historians strive to write a narrative that is a "real" story written as much as possible from inside sources about hitherto unknown or misunderstood activities and experiences of people in the past. It is a story usually intended for an audience of the successors of these actors whether they are their descendants or a population succeeding them in the same area. ${ }^{1}$

Let us gratefully remember Jan Vansina and strive to continue the journey he began.

1 Jan Vansina, "De Vita Sua," Society 53-3 (2016), 240-245. 